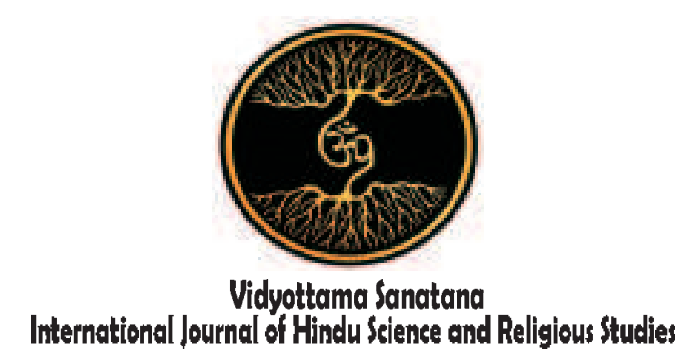

Vol. 1 No. 2 October 2017

\title{
The Educational Value of Hinduism on the Gumi Suda Ceremony at the Birth of the Twin Babies with Different Genders (Case Study at Pakraman Village of Ketewel, Sukawati District, Gianyar Regency)
}

\author{
By: \\ Asthadi Mahendra Bhandesa, I Gede Putu Darma Suyasa, \\ Ni Wayan Kesari Darmapatni \\ Sekolah Tinggi Ilmu Kesehatan Bali \\ Email:Bhandesa_asthadi@yahoo.com
}

\begin{tabular}{|l|l|l|}
\hline Received: August 29, 2017 & Accepted: September 15, 2017 & Published: October 30, 2017 \\
\hline
\end{tabular}

\begin{abstract}
This study aimed to identify the educational values of Hinduism on the Gumi Suda ceremony at the Birth of the twin babies with different genders in Pakraman Village of Ketewel, Sukawati District, Gianyar Regency. The data were collected by using interviews technique and literatures review. Furthermore, the data were analyzed through data reduction process or chosen according to the purpose of the research. The data analysis process was done continuously during the research from the beginning until the end of the research through the systematic tracking and arranging process of the transcripts of interviews, field notes and other materials. The Findings indicated that some of the educational values of Hinduism on the Gumi Suda ceremony at the birth of the twin babies with different genders in Pakraman Village of Ketewel, Sukawati District, Gianyar Regency are tattwa, ethics, ceremonial, health education and social educational values.
\end{abstract}

Keywords: Twin Babies with Different Genders, Educational Values of Hinduism, Gumi Suda Ceremony.

\section{Introduction}

Education is inseparable from culture and can only be accomplished in a community (Tanu, 2011: 112). Balinese culture is rich in concepts and also symbols because from the religious structure is funds by the teachings of Hinduism (Geriya, 2008: 149). The concepts is not the stagnation of abstract concepts without actualization, slowly is the operational concepts that bridge the idealistic domain with the 
empirical domain, thus becoming a reference in real life. The types of symbols as cultural richness manifest in art, ritual, social life, traditional knowledge systems, architecture, usadha and others (Geriya, 2008: 148).

Gumi Suda ceremony as one form of culture in Ketewel Village, District Sukawati, Gianyar Regency has been implemented from generation to generation. The background of Gumi Suda ceremony, there are community who gave birth to twins with different genders. Twin babies with different genders is the birth of two babies of different gender, both male and female by a mother in the same time in which the baby girl was born first. In the lontar of Raja Purana Pura Payogan Agung "bilamana ada warga masyarakat yang melahirkan kembar buncing maka diwajibkan melaksanakan upacara Gumi Suda di Catus Pata, dan mensthanakan kembali Ida Bhatara Ratu Mas Murub dan Mas Maketel". This happens as an essential belief in the Hindu community who lives in Ketewel Village, for those who have twin babies with different genders then the village will experience cuntaka.

The harmony between humans and nature will soothe and harmonize the rhythm of human life and its environment. In fact, every imbalance that occurs in community causes disharmony in cosmos (nature) and community. This disharmony will cause disaster, such as drought or other calamities. The harmony or equilibrium in a community is often the way they do their daily activities in which so-called cosmology can be realized (Prinst, 2003).

From the background of philosophy, theoretical, and empirical, this study is very important. This is due to the communities' understanding of the Guni Suda ceremony and values contained in it, it is because the community only do what is stated in the awigawig of a village or its implementation only, so it needs a study of Hindu religious education in the Gumi Suda ceremony at the birth twins in buncing condition. Few numbers of research relating to the birth of twin babies with different genders as a tradition that is still be the main cause of this disease where Gumi Suda ceremony is still held and the belief in the life of the community in pakraman village of ketewel, sukawati district in gianyar regency.

\section{Methods}

\subsection{The Location of the Research}

The research was conducted in Ketewel Village, Sukawati District, Gianyar Regency. Ketewel village was chosen as the location of the research because in Ketewel village there is still a belief about sebel of village by villagers when there is a family that gave birth to twin babies with different genders, and this tradition is still going on nowadays.

\subsection{Types of Research}

The design of this research was done by three stages of data collection starting from observation, interview and literature study. Furthermore, the data were inventoried, identified, processed and analyzed based on the qualitative methods to find answers to the problems of this study. The descriptive method used to see the nature of research data, such as the aspect of educational values of Hinduism in the Gumi Suda ceremony on the birth of twin babies with different genders. On the other hand qualitative methods with religious approach, sociology and anthropology were used when the data collection and discussion, which was emphasized on the aspect of data quality. This approach has great relevance because religion is also sociocultural.

\subsection{Data Collection Techniques}

The data were collected by using interview techniques and literature study. Interview techniques used in this study to obtain various information, such as oral information from informants related to the problem of study. The

9ak Educational value of Hinduism on the Gumi Suda Ceremony at the Birth 
interview guidelines had been prepared in such a way and openly. That was easily understood by informants and researchers could capture data easily, information, information through knowledge, opinions, and ideas from informants on various matters relating to the object of research. In addition the interviews in this study also used literature study techniques. Literature analysis in this research was done by tracing documents and reports relating to the problems and existence that lead to the educational values of Hinduism in the Gumi Suda ceremony on the birth of twin babies with different gender.

\subsection{Data Analysis}

The technique of data analysis used in this study were qualitative data analysis techniques proposed by Miles and Huberman (1992) covering three concurrent activities, namely 1 ) data reduction, 2) data presentation and 3) conclusion (verification) (Basrowi and Suwandi, 2008: 209). Analysis was used to analyze data from observation and interview. Qualitative data were tabulated based on the educational values of Hinduism, so it could be seen from the reliability and validity. In the process of data analysis that carried out throughout the study and carried out continuously from the beginning to the end of the study. Through the systematic process of tracking and arranging the interview transcripts, field notes and other materials.

\section{Results And Discussion}

3.1 The assessment of the Educational Values of Hinduism in Gumi Suda Ceremony at the Birth of Twin Babies with Different Gender

Local wisdom was a life view, science, and various life strategies tangible activities undertaken by local communities to answer various problems in the fulfillment of theirneeds. In addition, local wisdom could also be interpreted as a system in the social, political, cultural, economic, and environmental order of living in local communities (Endraswara, 2010: 1). Local wisdom in Bali was not something that exist without a reason, but everything must be caused by the fundamental factors. In reality the existence of event has undergone periodization so that what had passed and experienced become a discourse only. Regarding a cause was sometimes not able to be exposed clearly and plainly, caused by the lack of primary and secondary sources that could be proposed as a relevant reference source to be able to provide an overview and guidance of its development. Like one of them about the existence of local wisdom related to the implementation of Gumi Suda ceremony in Ketewel Village, Sukawati District, Gianyar Regency.

Gumi Suda ceremony can not be separated with the development of a global perspective that colored the modernity that has swept the world nowadays. Before the influence of globalization that is in pre-modern times the Balinese community has been carrying out all activities including the twin babies with different genders tradition with the concept of masula masuli which was no longer implemented. The existence of educational values in the Gumi Suda ceremony on the birth of twin babies with different genders became the foundation of the tradition of twin babies with different genders still carried out until now and contained in awig-awig of the village.

There were several factors that affect the culture including religious ceremonies and the custom of traditions which are undergoing some changes. For the community of the Ketewel village, Gumi Suda ceremony is a legacy and belief of the purana that exists and has been carried on for generations if there are births of twin babies with different genders. Gumi Suda ceremony as a tradition that is believed to be an intrinsic culture and a reflection of the religiosity for community of Ketewel Village. The existence of the Gumi Suda ceremony in 
its' present form, could not be separated from local wisdom and some factors that influence some factors, such as educational factor, experience (religious attitude) factor, the factor of need and the factor of the process of verbal thinking or process of thought.

Local wisdom is a human effort by using the sense of theirs (cognition) to act and act on something, objects, or events that occur in a certain space. As a term wisdom is often defined as 'wisdom/produnce', wisdom is understood as a person's ability to use his or her mind in acting or act as a result of his/her judgment of something, object, or event. Meanwhile, local refers to a limited interaction space with a limited value system. As the interaction space in it involves a pattern of relationship between man and other man or man with his physical environment. Substantially, local wisdom is the prevailing values in a community. Values that are believed to be true and become a reference in the daily behavior of local people (Ridwan, 2007).

The statement above indicated that the existing local wisdom has been formed from the ability to use the mind and mind in acting towards objects in a certain space that involves the pattern of interrelated relationships between humans and the environment. The pattern of local wisdom is poured in the form of awigawig in Ketewel Village about the Gumi Suda ceremony. Gumi Suda ceremony is implemented by the community of ketewel village as stated in awig-awig, but it is necessary to study the educational values of hinduism, the understanding of the educational values of hinduism because it is done from the preparation until the ceremony is completed and executed only if there are births of twin babies with different genders. In the implementation of it, it should not be separated from the sacred libraries of vedas and other Hindu literature and instructions (bhisama) from ancestors (leluhur).

\subsection{Educational Value of Phylosophy (Tatwa)}

Tatwa in Hinduism is not only to seek the truth, but tattwa could be interpreted as knowledge to discover the essence of everything that exists in depth. Overall the value of tattwa is all that is useful in religious life, especially Hinduism.

According to its 'awig-awig', Pakraman Village of Ketewel, Sukawati, Gianyar Regency, Bali, manakan is a birth that is considered make the impurity upon the village (ngeletehin gumi). This is because because one of villagers 'manak salah', in this case, giving birth to twin boy and girl. In which in this case the baby girl who was born first. When this happens then the villagers who have twin babies with different genders will report to the leader of pakraman village called as bendesa pakraman. Furthermore, the bendesa pakraman will hold a meeting called paruman sabda desa or village meeting by meeting with leader of hindus' ceremonial (sulinggih) in Ketewel village, Sukawati, Gianyar regency. In this meeting, there will be discussion about the Gumi Suda ceremony, the negotiations will be held between customary bendesa and sulinggih about the good day to perform Gumi Suda ceremony, and how to prepare it.

Associated with the birth of twin babies with different genders and the implementation of the Gumi Suda ceremony, Jero Mangku Gede Pura Payogan Agung as the keeper (pengempon) and responsible person in the implementation of the Gumi Suda ceremony that revealed as follows.

"Ketika ada seseorang yang melahirkan bayi kembar buncing maka akan dilaksanakan upacara Gumi Suda, yang dipersembahkan untuk menyucikan diri dalam artian telah terdapat seorang bayi kembar lahir yang disebut sebagi bayi lahir kembar buncing. Selain itu, di Desa Ketewel

916 Educational value of Hinduism on the Gumi Suda Ceremony at the Birth 
dilaksanakan upacara Gumi Suda untuk menciptakan keharmonisan semua mahluk (sarwa prani hitang kara) termasuk Bhuwana Agung dan Bhuwana Alit dengan caru Gumi Suda".

The phrase above shows that the Suumi Gumi ceremony will be held in Ketewel Village when the citizens have or give birth to twin babies with different genders. In the implementation of the Gumi Suda ceremony is meant to be able to purify humanity (bhuana alit) and create harmony between fellow humans and the environment (bhuana agung).

In ancient times developed a myth that says if the king gave birth to twins then the earth will be good and happy. However, if ordinary people who gave birth to twins then regarded as a disgrace. It because the people rival the position of kings and kingdoms. Thus, the person who gave birth to the twins, along with the baby, would be isolated in a lonely place or on cemetry (setra) for 42 days. After the ceremony the family was allowed to go home. In addition, the cost for a twin-born baby ceremony is funded by the family itself. However, in 1951 the government issued a regulation on the prohibition of imposing sanctions on families who gave birth to twin babies with different genders. Since then, there is no longer a community that gives fines to someone who gave birth to twin babies with different genders.

In culture point of view, there were several patterns of change that is evolution, diffusion, acculturation, and innovation. Evolution is the development of a community that has evolved slowly from the lowest and simplest level, to ever increasingly high and complex levels. This evolutionary process will always be experienced by all human beings on this earth though with different speed (Koentjaraningrat, 1987:31). The development of this community that alsoinfluences the changing implementation of the Gumi Suda ceremony and the birth of twin babies with different genders in Ketewel Village. According to Jero Mangku Gede Pura Payogan Agung,

"Di Desa Ketewel, Kecamatan Sukawati, Kabupaten Gianyar tidak menganut paham masula masuli namun terdapat istilah memada dengan nama Ida Ratu Mas Makentel Mas Mapurub sebagai pendamping di Pura Payogan Agung, beliau akan pergi ke gunung semeru. Setelah masyarakat melakukan penyucian diri ke segara, guru piduka dan upacara Gumi Suda di catus pata dan balai desa, maka Ida Bhatara akan kembali. Sehingga pada saat seseorang melahirkan bayi kembar buncing, maka Desa Ketewel disebut sebagai cuntaka. Cuntaka disini berarti masyarakat desa dilarang melakukan kegiatan keagamaan selama 42 hari atau sebelum upacara Gumi Suda dilaksanakan. Segala bentuk upacara dewa yadnya akan ditiadakan selama hari tersebut"

The statement above provides information that the people of Ketewel Village do not embrace masula masuli like ancient times, but know the term equals (memada) the realization of Ida Bhatara in this case Ida Mas Mas Maketel Mas Mapurub as a companion at Pura Payogan Agung, so that if there are citizens who gave birth twin babies with different genders then the village experiencing impurity (cuntaka or sebel) of village in the sense of not be allowed to carry out a religious ceremony before the Gumi Suda ceremony is held.

\subsection{Educational Value of Ethics (Susila)}

The educational value of ethical or moral at Gumi Suda ceremony in Ketewel village closely related to the concept of Tri Hita Karana, a harmonious relationship of humans with Ida Sang Hyang Widhi Wasa, human with environment, and human with others. When viewed from the implementation of the Gumi 
Suda ceremony, then susila or ethics become the second aspect of the basic framework of Hinduism which acts as a supporter of the purity of yadnya ceremony. Susila is a good behavior and noble character in accordance with goodness (dharma in religion). Religious ceremonies could not be separated from the moral values that serve as the guidelines of implementation that determine the quality of yadnya. Yadnya ceremony would not have mean if not based on the attitude and personality both by the organizers and implementers of yadnya.

The result of interview with Susilawati tanteri could be seen that the respondent was able to face the natural stress when knowing that by giving birth to twin babies with different genders where female baby born first would cause his village impure or cuntaka moreover the birth of twin babies with different genders is adjacent to the kuningan day.

"Saat tahu satunya bayi saya laki-laki, saya dan suami senang sekali tetapi kami sadar bahwa akan menjadi kembar buncing. Ditambah saya mendengar cerita bahwa 30 tahun yang lalu sempat ada kelahiran kembar buncing juga dan mereka tinggal dikuburan. Saya merasa cemas jika nantinya tinggal dikuburan hanya saja bahagianya lebih banyak waktu itu karena ada anak laki-lakinya"

In addition, the resident was able to express his emotions appropriately and maintain his emotional stability in order to remain positive.

"Biasanya operasi sesar dirawat di rumah sakit hanya dua hari tapi saya sampai lima hari tinggal di rumah sakit. Sebelum keputusan ditentukan saya sempet dengar kabar kalau saya harus tinggal dikuburan, waktu itu saya nangis secara kenyataanya anak yang wanita cewek keluar duluan. Tapi saat itu saya enggak mau terlalu banyak berpikir agar tidak stress. Saya jalani aja lagian sekarang jaman sudah modern pasti ada pilihan lain"

Respondents were also able to accept the nature of the situation which is supported by the statement of Susilawati Tanteri as follows.

"Setelah sebelan 42 hari dan segala banten (sarana-prasarana upacara) sudah selesai saya dan anak-anak beserta masyarakat desa ikut menyaksikan pelaksaan upacara, pertama upacaranya di perempatan setelah itu dilanjutkan ke kuburan dan yang terakhir ke pura. Saya merasa baik-baik saja meskipun ada tradisi ini dimana saya membuat desa sebelan. Menurut saya adatnya masih masuk akal dan tidak lagi ada yang harus tinggal dikuburan seperti rumor yang dikatakan sebelumnya”.

\subsection{Education Value of Ceremony (Upacara and Upakara)}

Gumi Suda ceremony is an implementation of yadnya or sincere sacred sacrifice and most widely seen by the public. In performing a ceremony was also required the use of ceremony (upakara) or offering (banten), in the implementation, it required a process of learning and education, so that in the ceremony element of education always exists and follows the yadnya ceremony. The aspect Yadnya implementation is very necessary in the future, so the implementation of the ceremony will not be separated from the existing provisions in the sacred literature (embodied in the Hindu law) and local wisdom of community. Ketewel village people strongly believe that in life as human beings must be able to realize harmony with each other. If the absence of balance in life causes disharmony of human life.

Before the Gumi Suda ceremony, the community of Ketewel village through working together (ngayah) will prepare all forms of facilities, infrastructure and the necessary offering for the Gumi Suda ceremony. Preparations would be held for 12 days before

918 Educational value of Hinduism on the Gumi Suda Ceremony at the Birth 
the ceremony is held. The villagers of Ketewel Village would be divided in turns to prepare the ceremony. While on the day of the ceremony, all villagers participated in the ceremony. The parties that play a role in the implementation of Gumi Suda ceremony are the bendesa pakraman, brahmins, the Jero Mangku Khayangan Tiga, Jero Mangku Khayangan Alit throughout Ketewel Village. After the Gumi Suda ceremony is implemented, then the entire Ida Bhatara would be back. Along with that ceremony, it means that the community of Ketewel Village is no longer impure (cuntaka). Thus, people able to perform religious activities as usual. Based on interview with Leader (Kelian) of Ketewel Village about the implementation of Gumi Suda ceremony as follows.

"Pelaksanaan upacara Gumi Suda juga merupakan tradisi yang sudah berlangsung secara turun temurun, biasanya upacara dilaksanakan setelah 40 hari dari kelahiran sang bayi, dari desa pakraman selama 15 hari sebelum hari $H$ sudah dilaksanakan acara ngayah. Pelaksanaan upacara dengan menghadirkan bayi yang lahir kembar buncing, mendekatkan masyarakat dengan Tuhan, dan masyarakat juga mendekatkan dengan sesama serta menjaga keharmonisan di lingkungan desa pakraman ketewel"

The statement above provides information that the implementation of Gumi Suda ceremony as a tradition that has been going on for generations, and the community involved in the ceremony process so as to create a harmonious relationship of the community with God, the community with others and also with the environment. However, due to the time changing and the increased activity of the villagers, the re-holding of paruman or village meetings about the length of the impurity or cuntaka day from the birth of twin babies with different genders. Based on the results of the negotiations with the villagers, bendesa, paruman agung and sulinggih opinion, then the cuntaka of the birth of twin babies with different genders shortened to 12 days of impurity/ cuntaka. In addition, based on interviews with Kelian of Ketewel Village regarding cuntaka as follows.

"Pada saat ini warga yang memiliki bayi kembar buncing, pada saat cuntaka hanya tidak diperbolehkan untuk melakukan persembahyangan di pura serta mengikuti upacara keagamaan. Sehingga, warga yang memiliki bayi kembar buncing masih bisa melakukan aktivitas keluar rumah"

This is in contrast with the tradition carried out in ancient times, where community who had twin babies with different genders should not go out during the cuntaka day. This causes the family who was in the cuntaka could not go out of the house because it was considered still impure/sebel or cuntaka. This certainly obstruct the activities and the families concerned could not do their activities.

\subsection{Educational Value of Health}

The World Health Organization defines Health Education as an effort consisting of conscious opportunities built for the learning that involving several forms of communication designed to improve health literacy, including increasing the knowledge, and developing a conducive life skills to the health of individuals and communities. The Gumi Suda ceremony is carried out as an activity in which it contains the educational value of health, health education in question is health education that related to the ability of a person in performing daily activities, achieving health, maintaining adequate nutrition and ideal body weight, avoiding drug dependency and Alcohol or cigarettes as well as generally doing positive living habits. This is 
as expressed Susilawati Tanteri, mother who gave birth to the following twin babies with different genders.

"Setelah lima hari dirawat di rumah sakit, akhirnya saya diperbolehkan pulang karena sudah ada keputusan dari desa bahwa saya boleh tinggal di rumah, saat itu selama sebulan tujuh hari (42 hari) saya tidak boleh ke dapur dan juga sembahyang tetapi karena tempat kerja saya dekat rumah jadi saya biasa melakukan aktivitas saya sehari-hari walaupun masih dalam masa sebelan (suatu keadaan tidak suci menurut pandangan agama Hindu) di desa"

Based on the interviews of the respondents above, it could be stated that the from the physical dimension, respondents still able to perform their daily activities in working and maintaining health was by visiting health services related to the health of the twin babies with different genders. Here is Susi Tanteri's statement

"Untuk imunisasi harus tetap. Kalau seandainya saya dilarang saya pasti bakalan berontak. Kedua anak saya saat lahir itu beratnya 3,5 kg dan $3 \mathrm{~kg}$ jadi sehat"

Based on the results of the analysis of the physical dimension, respondents have no problems in terms of daily activities and in seeking health services related to maintaining the health and her babies. Viewed from the context of health, even after a mother gave birth for 42 days is a period of childbirth where the mother was expected to rest to restore health. This is in line with the tradition in Bali where they are not allowed to go to places of worship such as temples because of their impurity/ cuntaka or so that they able to be more focused in taking care of her babies and restore her health condition.

\subsection{Educational Value of Social}

The implementation of Gumi Suda ceremony in Ketewel Village, Sukawati, Gianyar Regency was implemented with the use of the village funds as well as the regulated APBD. Community does not need to spend privately for the implementation of Gumi Suda ceremony. Thus, the implementation of Gumi Suda ceremony does not incriminate families who have twin babies with different genders. The ability of a person to interact well with others and the environment, fostering and maintaining familiarity with others and appreciating and tolerating different beliefs. Based on the results of interview analysis, both respondents who have twin babies with different genders and people in the Ketewel village not experience problems in interacting each other. There was no limit for them interacting in social life even if it was in a sebel or cuntaka condition. Similarly stated by Susilawati Tanteri.

"Walaupun karena melahirkan bayi kembar buncing saya tetap berinteraksi dengan masyarakat luar sama seperti sebelumnya. Mungkin ada beberapa hal yang membuat saya merasa sedikit terganggu ketika masyarakat mengatakan saya memiliki anak salah (kembar buncing), sebenarnya bukan salah sang anak yang lahir buncing tetapi saya mengerti alasan dikatakan seperti itu karena dikatakan bahwa melahirkan anak kembar buncing menyamai sesuunan (Tuhan) sehingga hal tersebut tidak wajar atau salah. Jadi saya tidak mau stres dengan hal tersebut"

Similar to I Wayan Arta Sandra's response as Klian Dinas (Official Head of community) in Ketewel Village that:

"Pada saat ada kelahiran bayi kembar buncing, masyarakat mengalami sebel

T190: Educational value of Hinduism on the Gumi Suda Ceremony at the Birth 
atau cuntaka sehingga beberapa masyarakat mengalami kesulitan yaitu tidak dapat melaksanakan upacara dewa yadnya sebagaimana yang sudah direncanakan. Akan tetapi karena kelahiran memang tidak bisa diatur, maka dari itu masyarakat merespon dengan baik dan tidak mengeluh dengan adanya kelahiran bayi kembar buncing ini"

Meanwhile, according to Klian Adat (Headman of community) of Ketewel Village, Nyoman Yasa, that through the implementation of Gumi Suda ceremony which is a tradition in Ketewel village able to hereditary practice the teachings of Hinduism namely Tri Hita Karana where the harmonious relationship of human with God, human with human itself and also human with nature or the environment, as it is said as follows.

"Pelaksanaan upacara Gumi Suda dengan menghadirkan bayi yang lahir kembar buncing, dapat mendekatkan masyarakat dengan Tuhan, juga dengan sesama serta menjaga keharmonisan di lingkungan desa Pekraman Ketewel. Saya rasa lebih baik melaksanakan upacara ini karena sudah menjadi awig-awig (aturan desa), pada umumnya masyarakat merespon positif dan masyarakat tidak merasa diberatkan dengan adanya kelahiran bayi kembar buncing. Selain itu, ada kekhawatiran jika tidak melaksanakan upacara pada saat kelahiran bayi kembar buncing ini terkait dengan kita memiliki sesuunan Gedong Kembar”.

\section{Conclusion}

Based on the results of research and data analysis could be raised the following conclusions, the educational value of Hinduism in the ceremony of Gumi Suda in Ketewel Village, Sukawati, Gianyar regency was the educational value of psychology, the educational value of ethics, the educational value of ceremony, the educational value of health and educational value of social.

\section{References}

Artadi, I Ketut. 2011. Kebudayaan Spiritualis. PT. Offset BP : Denpasar.

Azra, A. 2000. Pendidikan Agama Islam Pada Perguruan Tinggi Umum. Jakarta: Depag R.I.

Bertens, K. 2007. Etika. Jakarta: PT Gramedia Pustaka Utama.

Basrowi dan Suwandi. 2008. Memahami Penelitian Kualitatif. Jakarta: Rineka Cipta.

Dharmojo. 2005 Sistem Simbol dalam Munaba Waropen Papua. Jakarta: Departemen Pendidikan Nasional.

Endraswara, Suwardi. 2011. Metodologi Penelitian Sastra (Epistemologi, Model, Teori, dan Aplikasi). Yogyakarta: CAPS.

Geriya, I Wayan. 2008. Transsformasi Kebudayaan Bali Memasuki Abad XXI. Surabaya: Paramita.

Glock, C.Y. \& Stark, R. 1965. Religion and Community Intension. Chicago: Rand Mc. Nally dan Co.

Kozier, E.B, Erb, G. L, et. All. 1995. Fundamental of Nursing: Concept, Process and Practice. 5 th ed. California: AddisonWesleyPubl

Marriner-Tommey, A. 1994. Nursing Theorist and Their Work, 3rd ed. St. Louis: MosbyCompany

Moleong, MA Lexy. 2005. Metodologi Penelitian Kualitatif. Bandung: PT Remaja Rosdakarya.

Prinst, Darwin. 2002. Kamus Karo Indonesia. Medan: Bina Media. 
Ratna, Nyoman Kutha. 2010. Metodologi Penelitian Kajian Budaya dan Ilmu Sosial Humaniora pada Umumnya. Yogyakarta: Pustaka Pelajar.

Ridwan, Nurma Ali. 2007. Landasan Keilmuan Kearifan Lokal, dalam Jurnal Studi Islam dan Budaya Ibda' Vol. 5 No. 1 Jan-Jun 2007, hal 27-38 P3M STAIN Purwokerto.

Roy S.C-Andrews H.A. 1991. The Roy Adaptation Model: The Definitive Statement, California: Appleton \& Large

Surasmi, Wuwuh Asrinining. 2012. Menggugah Kesadaran Guru dalam Kearifan
Lokal pada Era Globalisasi. UPBJJ Surabaya.

Tanu, I Ketut. 2011. Pendidikan Agama Hindu di Tengah Masyarakat Modernisasi. Denpasar : Yayasan Sari Kahyangan Indonesia.

Thontowi, A. 2012. Hakekat Religiusitas. http:/ /www.sumsel.kemenag.go.id, diakses 4 September 2012.

Yatna dan Supartha. 1995. Kembar Buncing di Bali. Denpasar: Bali Post

Wiana, I Ketut. 2002. Memelihara Tradisi Weda, PT offset BPDenpasar. 